\title{
Research on the Influence of Non-Tradable Share Reform on Cash Dividends in Chinese Listed Companies
}

\author{
Fang Zou (Corresponding author) \\ Business School, Sichuan Agricultural University \\ No.614, Building 1, Students Apartment \\ Dujiangyan School, Sichuan Agricultural University \\ Chengdu 611830, China \\ Tel: + 86-136-8817-1018Ｅ-mail: fangtougao@163.com \\ Fangjie Su \\ Sichuan Branch, Industrial and Commercial Bank of China \\ No.124, Building C, Students Apartment, Liulin School \\ Southwestern University of Finance and Economics \\ Chengdu 611130, China
}

Tel: +86-136-8817-1018Ｅ-mail:sufangjack@163.com

Wei Peng

Business School, Sichuan Agricultural University

Chengdu 611830, China

Tel:+86-135-4025-3967_E-mail:zf1018@sina.com

Received: February 2, $2012 \quad$ Accepted: February 27, $2012 \quad$ Published: May 15, 2012

doi:10.5430/ijba.v3n3p11

URL: http://dx.doi.org/10.5430/ijba.v3n3p11

This paper is sponsored by Social Science Association of Sichuan Agricultural University.

\begin{abstract}
In this paper, authors analyze the influences of non-tradable share reform on cash dividends in Chinese listed companies and find that the distribution intensity of cash dividends has been weakened in listed companies after the non-tradable share reform. The research shows that the non-tradable share reform weakens the "tunneling" effect of large shareholder cash dividends. While non-tradable shares of large shareholder are in circulation, the large shareholder agency problem is further eased.
\end{abstract}

Keywords: Non-Tradable Share Reform, Large Shareholder Agency Problem, Tunneling, Cash Dividends

\section{Introduction}

Theories of cash dividends and schools in foreign countries are various. Currently the dominant point is to use the signaling theory and the agency theory to explain the dividend policy. The dividend signaling theory agrees that under the circumstance of information asymmetry, listed company can send the information about its future profitability to the market by means of dividend policy.

The agency theory agrees that dividend policy is a mechanism for solving the agency problem in listed companies between internal staff and external people. For the listed company, cash dividends can not only solve the agency problem between the management level and the shareholders, but also settle the agency problem between controlling shareholders and minority shareholders. However, many domestic researches have shown that cash dividends are the 
way for the large shareholder of listed company occupying interests of minority shareholders. Juanjuan Huang et al (2007) thought that in a market neglecting the protection for legal rights and interests of minority shareholders, plus the concentrated shareholding in listed company, the large shareholder had the motive for robbing minority shareholders by dividends. In their opinion, the dividend policy, developed by the listed company that is the supplier of dividends, was only to meet the large shareholder's needs for dividends, but neglect the needs of minority shareholders. Because of the special capital market system in China and the lack of legal protection for rights and interests of investors, the interest conflict between large shareholders and minority shareholders leads to higher cash dividends instead of lower cash dividends. In other words, high cash dividends are the way for large shareholders occupying the listed company.

The non-tradable share reform, implemented in 2005 in China, gives the non-tradable shares hold by large shareholders the right of circulation. The consideration in the reform makes the equity costs of large shareholders close to that of minority shareholders. At the times of post non-tradable share reform and full circulation, what would the new characteristics of cash dividends tend to be in listed company? In this paper, we will study the influences of non-tradable share reform on cash dividends in listed companies.

\section{Research Hypothesis}

In the framework of cash dividend agency theory, Jensen (1986) thought that cash dividends could reduce the agency costs at the management level. In order to alleviate the principal-agent problem, the listed company should distribute more cash dividends and reduce free cash flows in the company. Foreign studies agreed that dividend policy can be used as a tool to solve the agency cost problem. To increase the dividends can reduce the agency costs.

However, China's cash dividend policy, marked with some special Chinese characteristics, shows different effects from foreign dividend policies. Under the circumstance of large shareholders' super controlling powers and before the non-tradable share reform, non-tradable shares are not in circulation in second market. Large shareholders cannot get capital gains by holding non-tradable shares. If do not transfer non-tradable shares by agreements, cash dividends would be the only legal way for large shareholders getting gains from their non-tradable shares. Besides, the equity costs for non-tradable shares differ significantly from that of tradable shares. The same cash dividends per share produce higher yields for shareholders of non-tradable shares than that for shareholders of tradable shares. During the period before the non-tradable share reform, cash dividends were often taken as a tool for large shareholders "transferring resources" or "cashing" in listed companies (Guangyong Lei, 2007).

The structure of non-tradable shares and tradable shares produces "two kinds of shares with different natures and prices" in internal listed companies in China's capital market. The non-tradable share reform tries to form a mechanism for balancing and coordinating interests between shareholders of non-tradable shares and shareholders of tradable shares, eliminating the institutional differences for share transfer in capital market. Yinong Huang (2008) agreed that after the non-tradable share reform, cash dividends would not cause different yields for investors and the motive for large shareholders occupying interests of minority shareholders by cash dividends would be weaken. In this paper, we agree that the non-tradable share reform cannot stop large shareholders transferring interests by cash dividends, but the "tunneling" effect of large shareholders' cash dividends would be weaken. Therefore, we propose the following hypotheses.

Hypothesis 1: After the non-tradable share reform, cash dividends in the listed company have been weakened.

The concentration degree of equity determines the large shareholders' subjective wish for cash dividends. The higher the proportion of shareholding of large shareholders, the more large shareholders tend to occupy interests of minority shareholders by cash dividends (Huacheng Wang et al, 2007). Researches by Juanjuan Huang et al (2007) showed that the more concentrated the shareholding, the higher the probability of paying cash dividends was, and the higher the amount was. Hong Xiang (2007) agreed that after the non-tradable share reform, large shareholders do not change their preference for cash dividends. There was a positive correlation between proportion of shareholding of large shareholders and cash dividends per share. In this paper, we argue that the listed company with high cash dividends before the non-tradable share reform suffers a lot from the non-tradable share reform. Present researches and documents show that there is a positive correlation between the level of cash dividends in listed company and the proportion of shareholding of large shareholders. Thus, the hypothesis:

Hypothesis 2: In the listed company with higher proportion of shareholding of large shareholders, cash dividends will be weaken by a big margin, after the non-tradable share reform. 


\section{Research Design}

\subsection{Sample Selection}

This research takes listed companies that accomplished the non-tradable share reform and achieved full circulation by the end of 2009 as the objects, analyzing the data before the non-tradable share reform, after the non-tradable share reform, and the full circulation period, from 2003 to 2009. In addition, this paper processes data in the following aspects. First, because of the special nature of financial industry, this paper excludes data of financial industry. Second, eliminate some missing financial data. Finally we get 2373 sample data. The financial data of listed companies in this paper are mainly from the database CSMAR of GTA, Shenzhen, China. The data of equity structure are mainly from the database CCER of SinoFin, an information service company.

\subsection{Variable Choice and Model Construction}

In this research, we use the distribution intensity of cash dividends as the explanatory variable to assess the cash dividend policy of listed company. The distribution intensity of cash dividends refers to the amount of cash dividends in listed company, reflected by cash dividends per share. Use Tobit regression to study the influences of non-tradable share reform on distribution intensity of cash dividends in listed company.

$\mathrm{Cdps}=\mathrm{b}_{0}+\mathrm{b}_{1} \operatorname{Ref}+\mathrm{b}_{2} \mathrm{Cir}+\mathrm{b}_{3} \mathrm{Cr}+\mathrm{b}_{4} \mathrm{Cr} 2{ }_{-} 5+\mathrm{b}_{5} \operatorname{Ref} \cdot \mathrm{Cr}+\mathrm{b}_{6} \mathrm{Cir} \cdot \mathrm{Cr}+\mathrm{b}_{7}$ Eps $+\mathrm{b}_{8} \operatorname{Size}+\mathrm{b}_{9} \mathrm{Lev}+\mathrm{b}_{10} \mathrm{Gro}+\mathrm{b}_{\mathrm{i}} \mathrm{Indu}_{\mathrm{i}}$

The operational definitions of all variables are displayed in Table 1.

\section{Empirical Analysis}

\subsection{Descriptive Statistics}

According to the general samples, the mean of cash dividends per share is 0.08 and the maximum is 1.29 , what indicates that some listed companies distribute more cash dividends. 55\% of samples distribute cash dividends. The mean of concentration ratio is $40.1 \%$. According to the international threshold standard $10 \%$ for control right, calculations show that more than $98.9 \%$ samples exceed the standard 10\%. In Chinese listed companies, the first large shareholder has more powerful control over the listed company. The Cr2_5 is $14.2 \%$, far less than Cr. It means the power to balance the distribution of equities in the listed company is weak. The maximum of Lev reaches 7.33, indicating that some listed companies are in serious debts. Growth opportunities for listed companies are also diversified.

\subsection{Empirical Analysis Result}

Table 3 reports the regression result of distribution intensity of cash dividends in listed companies. In the model (1), the coefficient of Ref and Cir is significantly negative, which indicates that after the non-tradable share reform, the average distribution intensity of cash dividends in listed companies is decreasing significantly than before. The hypothesis 1 has been confirmed. In the model (2), the cross coefficient of Ref, $\mathrm{Cir}$, and $\mathrm{Cr}$ is negative and the later does not pass the test of significance, which indicates that the listed company with high $\mathrm{Cr}$ decreases the distribution intensity of cash dividends after the non-tradable share reform. According to general samples, the listed company with the high cash dividend policy before the non-tradable share reform suffers more impacts from the reform than the one with low cash dividend policy. However, at the times of full circulation, the distribution intensity of cash dividends decreases slightly. The hypothesis 2 has been confirmed. The model (3) and (4) can make a hierarchical regression of model (5) by the test of significance. In the model (5), the cross coefficient of Ref, $\mathrm{Cir}$, and $\mathrm{Cr}$ is significantly negative, which indicates that whether it is the post non-tradable share reform time or the full circulation time, the large shareholder's preference for cash dividends is weakening than that before the reform. The hypothesis 1 has been further confirmed. Besides, the cross coefficient of the later is smaller than that of the former, which indicates that after the full circulation, the large shareholder's preference for cash dividends is weak than that in the non- tradable share reform time.

\section{Conclusion}

In this paper, authors mainly analyze the influences of non-tradable share reform on cash dividends of large shareholders and draw conclusions as follow. (1) After the non-tradable share reform, the distribution intensity of cash dividends in listed companies is significantly decreasing. Then, in perspective of distribution of cash dividends, the large shareholder agency problem has been alleviated after the non-tradable share reform. (2) Large shareholders have the same proportion of shares. After the non-tradable share reform, the distribution intensity of cash dividends in listed companies has been reduced significantly. It means the large shareholders' preference for cash dividends is weak after the non-tradable share reform, which, from a different angel, confirms that the large shareholder agency problem has been alleviated after the reform. (3) Empirical analysis shows that the listed company with high cash dividends before the non-tradable share reform suffers more from the reform, in which the distribution intensity of cash dividends declines more significantly. (4) At the full circulation time the distribution intensity of cash dividends in listed companies is lower than that before the 
reform. After accomplishing the full circulation, the large shareholder's preference for cash dividends declines by a greater degree. In perspective of cash dividends distribution, as the non-tradable shares of large shareholders are in circulation, the large shareholder agency problem has been alleviated further.

\section{References}

Huang, J. \& Shen, Y. (2007). To whom do public corporate dividend policies cater? — an empirical evidence from Chinese public corporations. Accounting Research. No.8. p36-43.

Huang, Y. (2008). Analyze the cash dividends policy in listed companies in perspective of share structure reform. Chinese Enterprise Accounting of Villages and Towns. No.6. p35-37.

Jensen, M. C.. (1986). Agency cost of free cash flow, corporate finance and takeover [J]. American Economic Review. No.76. p323-329.

La Porta, R., Lopez-de-Silanes, F., Schleifer, A. \& Vishny, R. W. (2000). Agency problems and dividend policies around the world [J]. The Journal of Finance. No.55. p 1-33.

La Porta, R., Lopez-de-Silanes, F. , Shleifer, A. \& Vishny R. W. (2002). Investor protection and corporate valuation [J]. Journal of Finance. No.57. p1147-1170. http://dx.doi.org/10.1111/1540-6261.00457

Lei, G. \& Liu, H. (2007). The market process, the nature of final controlling shareholder, and the cash dividends behavior ----- the empirical evidence from Chinese A-share listed companies. Management World. No.7. p120-128.

Sarkar, J., S. \& Sarkar, K. Sen. (2008). Board of directors and opportunistic earnings management: evidence from India [J]. Journal of Accounting, Auditing and Finance. No.23. p375-400.

Xiang, H. (2008). Empirical study on impacting factors on cash dividends before and after the reform of share rights splitting. Accounting Research. No.6. p63-71.

Wang, H., Li, C. \& Lu, C. (2007). An empirical research on the influences of controlling shareholders on cash dividend policy in listed company. Management World. No.1. p122-127.

Table 1. The operational definitions of variables.

\begin{tabular}{|c|c|c|}
\hline Signal & Variable & Operational definition \\
\hline Cdps & Cash dividends per share & The ratio of cash dividends to the number of ordinary shares in listed company \\
\hline $\mathrm{Cr}$ & Concentration ratio & $\begin{array}{l}\text { The proportion of shares holding by the first large shareholder to total shares of } \\
\text { listed company }\end{array}$ \\
\hline $\mathrm{Cr} 2 \_5$ & Concentration ratio $2 \_5$ & $\begin{array}{l}\text { The proportion of shares holding by the second, third, fourth, and fifth large } \\
\text { shareholders to total shares of listed company }\end{array}$ \\
\hline Ref & $\begin{array}{l}\text { Non-tradable share } \\
\text { reform or not }\end{array}$ & $\begin{array}{l}\text { If the listed company accomplishes the non-tradable share reform but without full } \\
\text { circulation, } \operatorname{Ref}=1 \text {; otherwise, } \operatorname{Ref}=0 \text {. }\end{array}$ \\
\hline Cir & Full circulation or not & If accomplish full circulation, $\mathrm{Cir}=1$; otherwise, $\mathrm{Cir}=0$. \\
\hline Eps & Earnings per share & Divide the number of shares by annual net profits of the listed company \\
\hline Size & Size of listed company & The natural logarithm of total assets of listed company by the end of the year \\
\hline Lev & Asset-liability ratio & The ratio of total liabilities to total assets of listed company by the end of the year \\
\hline Gro & Total assets growth rate & The growth rate of total assets of listed company in current year than in last year \\
\hline Indu & $\begin{array}{l}\text { Industrial dummy } \\
\text { variable }\end{array}$ & The industry of listed company \\
\hline
\end{tabular}


Table 2. The descriptive statistics of general samples

\begin{tabular}{|c|c|c|c|c|c|}
\hline & Number of samples & Minimum & Maximum & Mean & Standard deviation \\
\hline Cdps & 2373 & .0000 & 1.2910 & .0818 & .1246 \\
\hline Cr & 2373 & .0449 & .8500 & .4010 & .1657 \\
\hline Cr2_5 & 2373 & .0022 & .5816 & .1427 & .1217 \\
\hline Eps & 2373 & -3.3000 & 4.5700 & .2045 & .4338 \\
\hline Size & 2373 & 16.8306 & 27.4877 & 21.4458 & 1.0590 \\
\hline Lev & 2373 & .0397 & 7.3315 & .5051 & .3044 \\
\hline Gro & 2373 & -.8297 & 13.9816 & .1425 & .4545 \\
\hline
\end{tabular}

Table 3. The regression result of distribution intensity of cash dividends

\begin{tabular}{|c|c|c|c|c|c|}
\hline & (1) & (2) & (3) & (4) & (5) \\
\hline Constant & $\begin{array}{c}-0.513 \\
(-7.798) * * *\end{array}$ & $\begin{array}{c}-0.547 \\
(-8.230) * * *\end{array}$ & $\begin{array}{c}-0.386 \\
(-5.932) * * *\end{array}$ & $\begin{array}{c}-0.432 \\
(-6.607) * * *\end{array}$ & $\begin{array}{c}-0.501 \\
(-7.557)^{* * *}\end{array}$ \\
\hline Ref & $\begin{array}{c}-0.041 \\
(-6.769) * * *\end{array}$ & $\begin{array}{c}-0.040 \\
(-6.502) * * *\end{array}$ & & & \\
\hline Cir & $\begin{array}{c}-0.073 \\
(-8.761) * * *\end{array}$ & $\begin{array}{c}-0.073 \\
(-8.692) * * *\end{array}$ & & & \\
\hline $\mathrm{Cr}$ & & & $\begin{array}{c}0.157 \\
(8.874)^{* * *}\end{array}$ & $\begin{array}{c}0.220 \\
(10.301)^{* * *}\end{array}$ & $\begin{array}{c}0.206 \\
(9.726)^{* * *}\end{array}$ \\
\hline $\mathrm{Cr} 2 \_5$ & & & & $\begin{array}{c}0.149 \\
(5.342)^{* * *}\end{array}$ & $\begin{array}{c}0.109 \\
(3.793)^{* * *}\end{array}$ \\
\hline $\mathrm{Ref} * \mathrm{Cr}$ & & $\begin{array}{c}-0.013 \\
(-0.358) * * *\end{array}$ & & & $\begin{array}{c}-0.043 \\
(-3.090) * * *\end{array}$ \\
\hline $\mathrm{Cir} * \mathrm{Cr}$ & & $\begin{array}{c}-0.061 \\
(-1.171)\end{array}$ & & & $\begin{array}{c}-0.110 \\
(-5.427) * * *\end{array}$ \\
\hline Eps & $\begin{array}{c}0.258 \\
(20.700) * * * \\
\end{array}$ & $\begin{array}{c}0.259 \\
(20.742) * * * \\
\end{array}$ & $\begin{array}{c}0.256 \\
(20.453) * * * \\
\end{array}$ & $\begin{array}{c}0.255 \\
(20.534) * * * \\
\end{array}$ & $\begin{array}{c}0.258 \\
(20.875) * * * \\
\end{array}$ \\
\hline Size & $\begin{array}{c}0.024 \\
(7.827) * * *\end{array}$ & $\begin{array}{c}0.025 \\
(7.868) * * *\end{array}$ & $\begin{array}{c}0.014 \\
(4.557) * * *\end{array}$ & $\begin{array}{c}0.014 \\
(4.546) * * *\end{array}$ & $\begin{array}{c}0.018 \\
(5.763) * * *\end{array}$ \\
\hline Lev & $\begin{array}{c}-0.109 \\
(-6.215) * * *\end{array}$ & $\begin{array}{c}-0.108 \\
(-6.202) * * *\end{array}$ & $\begin{array}{c}-0.100 \\
(-5.709) * * *\end{array}$ & $\begin{array}{c}-0.093 \\
(-5.308) * * *\end{array}$ & $\begin{array}{c}-0.092 \\
(-5.312) * * *\end{array}$ \\
\hline Gro & $\begin{array}{c}-0.001 \\
(-1.656) *\end{array}$ & $\begin{array}{c}-0.001 \\
(-1.648) *\end{array}$ & $\begin{array}{c}-0.001 \\
(-1.871)^{*}\end{array}$ & $\begin{array}{c}-0.001 \\
(-1.877)^{*}\end{array}$ & $\begin{array}{c}-0.001 \\
(-1.806)^{*}\end{array}$ \\
\hline Industry & Control & Control & Control & Control & Control \\
\hline Sample & 2373 & 2373 & 2373 & 2373 & 2373 \\
\hline Adjusted $\mathrm{R}^{2}$ & 0.560 & 0.560 & 0.554 & 0.557 & 0.567 \\
\hline
\end{tabular}

Notice: $* * *$ means the test value $\mathrm{Z}$ is in two-tailed significant at the level of $1 \%$; $* *$ means the test value $\mathrm{Z}$ is in two-tailed significant at the level of 5\%; * means the test value $\mathrm{Z}$ is in two-tailed significant at the level of $10 \%$. 